\title{
Społeczne budownictwo czynszowe jako usługa w ogólnym interesie gospodarczym
}

\section{Wprowadzenie}

Potrzeby mieszkaniowe należą do grupy potrzeb powszechnych. Oznacza to, że dotyczą każdego człowieka, niezależnie od tego, w jakim znajduje się okresie życia. W Polsce potrzeby mieszkaniowe - przynajmniej statystycznie - są na znacznie niższym poziome zaspokojenia niż w większości państw członkowskich Unii Europejskiej (UE) ${ }^{1}$. Wprawdzie badania przeprowadzone przez Ministerstwo Infrastruktury i Rozwoju w latach 2002-2014 wykazały poprawę sytuacji mieszkaniowej Polaków (spadek deficytu mieszkań z poziomu ok. 1,7 mln do ok. 0,5 mln miesz$k$ nn $\left.^{2}\right)$, to jednak wiele gospodarstw domowych nie może pozwolić sobie na nabycie bądź najem lokalu mieszkalnego na rynku komercyjnym³ ${ }^{3}$.

${ }^{1}$ W 2014 r. najwyższe wskaźniki przeludnienia wśród państw członkowskich UE odnotowano w Rumunii (52,3\%), na Węgrzech (44,6\%), w Polsce (44,2\%), Bułgarii $(43,3 \%)$ i Chorwacji $(42,1 \%)$. Z kolei najniższe wskaźniki przeludnienia odnotowano w Belgii (2\%), na Cyprze (2,2\%) oraz w Holandii (3,5\%). Ponadto Polska znajduje się w gronie państw o jednym z najwyższych wskaźników deprywacji mieszkaniowej (9,1\%), czyli wskaźników opisujących braki wyposażenia lokali mieszkalnych w podstawowe instalacje (takich jak łazienka, toaleta czy poziom oświetlenia) oraz zły stan techniczny. Dla porównania, w Finlandii, Holandii i Belgii problem poważnej deprywacji mieszkaniowej dotyka mniej niż 1\% populacji (Dane statystyczne dotyczace mieszkalnictwa, dane Eurostat z maja 2015 r., http://ec.europa.eu/eurostat/statistics-explained/index.php/ Housing_statistics/pl (dostęp: 16 V 2016).

${ }^{2}$ Deficyt mieszkań to różnica między liczbą zamieszkałych mieszkań a liczbą gospodarstw domowych.

${ }^{3}$ Uzasadnienie do rządowego projektu ustawy o zmianie ustawy o niektórych formach popierania budownictwa mieszkaniowego oraz niektórych innych ustaw, druk sejmowy nr 3586/VII kadencja z dnia 24 VI 2015 r., s. 6-7. 
Co więcej, wciąż nierozwiązanym problemem pozostaje niezadowalający stan techniczny znacznej części zasobów lokalowych. Jak wynika z danych GUS, ponad 1,3 mln lokali mieszkalnych mieści się w grupie tzw. lokali substandardowych ${ }^{4}$. W konsekwencji sytuacja mieszkaniowa osób o niskich dochodach urasta do rangi problemu społecznego, którego rozwiązanie staje się coraz pilniejsze, a przy tym coraz bardziej skomplikowane.

Jako jedną z propozycji uzupełnienia powyższych niedoborów w segmencie mieszkalnictwa wskazuje się rozwój społecznego budownictwa czynszowego. Tego rodzaju instrument jest z powodzeniem wykorzystywany m.in. w Belgii, Holandii, Niemczech, Danii czy Wielkiej Brytanii ${ }^{5}$. Również w Polsce od połowy lat dziewięćdziesiątych XX w. rozwijano społeczne budownictwo czynszowe. Przybrało ono postać budownictwa spółdzielczego lokatorskiego oraz budownictwa czynszowego realizowanego m.in. przez towarzystwa budownictwa społecznego. Niemniej jednak od 2010 r. społeczne budownictwo czynszowe miało znaczenie marginalne ${ }^{6}$.

Trend ten może odwrócić zapowiedziany przez rząd na początku czerwca 2016 r. program „Mieszkanie Plus”. Głównym celem projektowanego programu będzie stworzenie dostępu do mieszkań na wynajem oraz na wynajem z możliwością dojścia do własności. Program "Mieszkanie Plus" ma opierać się na trzech filarach, tj. na wsparciu budownictwa społecznego, mieszkaniach budowanych na gruntach skarbu państwa przez Narodowy Fundusz Mieszkaniowy oraz wsparciu oszczędzania na cele mieszkaniowe w ramach Indywidualnych Kont Mieszkaniowych. Dodatkowym elementem programu będzie wsparcie dla społecznego budownictwa czynszowego, realizowanego

${ }^{4}$ Dane uzyskane podczas Narodowego Spisu Powszechnego przeprowadzonego w 2011 r., za: Z. Rataj, Społeczne budownictwo mieszkaniowe i jego rola w zaspokajaniu potrzeb mieszkaniowych niezamożnych gospodarstw domowych w Polsce. Rozprawa doktorska napisana pod kierunkiem A. Przymeńskiego, Uniwersytet Ekonomiczny w Poznaniu 2015 r., publikacja dostępna wyłącznie z komputerów znajdujących się na terenie Biblioteki Głównej Uniwersytetu Ekonomicznego w Poznaniu, s. 71-72.

${ }^{5}$ Z. Rataj, op. cit., s. 161-175; M. Załęczna, Mieszkalnictwo społeczne w świetle przepisów o pomocy publicznej, „Świat Nieruchomości” 2014, nr 89, s. 33-34.

${ }^{6}$ Zob. szerzej raporty Najwyżej Izby Kontroli: z dnia 24 VI 2015 r. pn. Koordynacja polityki rodzinnej, s. 67-72; z dnia 11 XII 2012 r. pn. Gospodarowanie lokalami komunalnymi w budynkach mieszkalnych; z dnia 10 I 2012 r. pn. Realizacja zadań w zakresie gospodarki mieszkaniowej przez organy administracji rzadowej i jednostki samorzadu terytorialnego. 
przez samorządy, spółki gminne oraz towarzystwa budownictwa społecznego ${ }^{7}$.

W tym miejscu warto również zwrócić uwagę na funkcjonujący już program związany z rozwojem społecznego budownictwa czynszowego. Mowa mianowicie o programie przyjętym w drodze Ustawy z dnia 10 września 2015 r. o zmianie ustawy o niektórych formach popierania budownictwa mieszkaniowego ${ }^{8}$. Wspomniana nowela wprowadza nowy program budowy lokali mieszkalnych na wynajem, który stanowi uzupełnienie dotychczasowych instrumentów lokalnej polityki mieszkaniowej gmin. Zgodnie $\mathrm{z}$ art. 15a ust. 1 u.n.f.p.b.m. w ramach realizacji rządowego programu popierania budownictwa mieszkaniowego Bank Gospodarstwa Krajowego udziela finansowania zwrotnego poprzez udzielanie kredytów oraz organizację emisji obligacji i gwarantowanie ich nabycia. Należy jednak podkreślić, że finansowanie jest udzielane jedynie tym inwestorom, którzy podpiszą stosowną umowę z gminą właściwą miejscowo dla planowanego przedsięwzięcia inwestycyjno-budowlanego. Ponadto ustawodawca ograniczył grono potencjalnych inwestorów do trzech rodzajów podmiotów, tj. towarzystw budownictwa społecznego, spółdzielni mieszkaniowych oraz spółek gminnych ${ }^{9}$. Warto w tym miejscu podkreślić, że w Ministerstwie Budownictwa i Infrastruktury trwają prace nad Narodowym Programem Mieszkaniowym, którego jednym z filarów ma być właśnie społeczne budownictwo czynszowe ${ }^{10}$.

Założenia programu "Mieszkanie Plus”, a także nowe instrumenty finansowe przewidziane w u.n.f.p.b.m. prowadzą do wniosku, że budowa mieszkań na wynajem może osiągnąć niespotykaną dotąd skalę. Na tym tle powstaje pytanie o charakter wsparcia, jakie jest lub będzie

${ }^{7}$ Oficjalny komunikat na stronie Ministerstwa Infrastruktury i Budownictwa z dnia 3 VI 2016 r. pt. Rząd przedstawił program Mieszkanie Plus, http://mib.gov.pl/2-514324a4ec938-1797173.htm (dostęp: 8 VI 2016). Zob. M. Maśliński, A. Guminiak, Mieszkanie Plus - sa pierwsze założenia programu, "Portal Komunalny" z dnia 3 VI 2016 r., http://portalkomunalny.pl/mieszkanie-plus-sa-pierwsze-zalozenia-programu-332578 (dostęp: 8 VI 2016).

${ }^{8}$ Dz.U. poz. 1582, dalej "nowela u.n.f.p.b.m.”.

${ }^{9}$ Zgodnie art. 15 a ust. 2 pkt 3 u.n.f.p.b.m. „spółkami gminnymi” są spółki z ograniczoną odpowiedzialnością lub spółki akcyjne, w których gmina lub gminy dysponują odpowiednio ponad 50\% głosów na zgromadzeniu wspólników lub na walnym zgromadzeniu, niedziałające $\mathrm{w}$ formie towarzystwa budownictwa społecznego.

${ }^{10}$ R. Krupa-Dą̧rowska, Będa mieszkania dla rodzin z niskimi dochodami, "Rzeczpospolita” nr 64 (10397) z 17 III 2016. 
udzielane towarzystwom budownictwa społecznego, spółdzielniom mieszkaniowych oraz spółkom gminnym. Należy bowiem zauważyć, iż przysporzenia na rzecz tych podmiotów mogą zostać uznane za pomoc publiczną. Co więcej, art. 15a ust. 5 u.n.f.p.b.m. stanowi expressis verbis, że finansowanie zwrotne, które występuje na gruncie nowego programu budownictwa społecznego, stanowi rekompensatę z tytułu świadczenia usług publicznych w rozumieniu przepisów prawa Unii Europejskiej. Przyjęcie powyższego założenia niesie ze sobą daleko idące skutki prawne. Środki stanowiące tzw. rekompensatę z tytułu świadczenia usługi publicznej, czyli dopuszczalne w ramach wyłączenia zawartego w art. 106 ust. 2 Traktatu o funkcjonowaniu Unii Europejskiej nie wymagają notyfikacji, a ich kontrola ma charakter ex post. W rezultacie państwa członkowskie mają większą swobodę w stosowaniu działań pomocowych, które stanowią usługi świadczone w ogólnym interesie gospodarczym ${ }^{11}$. Nie można jednak zapominać, że o tym, czy dany środek stanowi pomoc publiczną, tudzież pomoc stanowiącą rekompensatę z tytułu świadczenia usług w ogólnym interesie gospodarczym, decyduje wyłącznie prawo wspólnotowe ${ }^{12}$.

Omawiany problem nabiera szczególnego znaczenia w przypadku wsparcia udzielanego na rzecz mieszkalnictwa. Wynika to z faktu, że udzielanie pomocy na rzecz społecznego mieszkalnictwa czynszowego stwarza ryzyko naruszenia interesów przedsiębiorców (deweloperów) działających na rynku komercyjnym. Wzrost dostępu do mieszkań utworzonych w ramach budownictwa społecznego może mianowicie prowadzić do spadku zainteresowania mieszkaniami, które są oferowane przez przedsiębiorców na rynku komercyjnym. Należy bowiem zaznaczyć, że istotny segment budownictwa społecznego stanowią mieszkania o umiarkowanych czynszach, oferowane osobom, które mają zbyt wysokie dochody, żeby uzyskać lokal socjalny, a jednocześnie zbyt niskie, aby sfinansować nabycie mieszkania z wykorzystaniem kredytu. W konsekwencji niewłaściwa realizacja programu społecznego budownictwa czynszowego może doprowadzić do naruszenia ogólnych reguł konkurencji. W praktyce takie zarzuty pojawiły się w związku z realizacją programów mieszkalnictwa społecznego w Szwecji, Holandii oraz Belgii ${ }^{13}$. Skargi na kształt tych programów

${ }^{11}$ Traktat o funkcjonowaniu Unii Europejskiej (wersja skonsolidowana), Dz.Urz. UE C 326 z 26 X 2012 r., poz. 0001-0390, dalej "TFUE”.

${ }^{12}$ Pomoc państwa. Wybrane zagadnienia, pod red. B. Kurcza, Legalis 2009.

${ }^{13}$ M. Załęczna, op. cit., s. 33-34. 
zgłaszali głównie deweloperzy. Ich zdaniem niektóre programy budownictwa społecznego prowadziły do dyskryminowania przedsiębiorców prywatnych, bądź też miały zbyt powszechny charakter (tj. mieszkania oferowane $\mathrm{w}$ ramach tych programów nie ograniczały się jedynie do osób najbardziej potrzebujących, były także dostępne dla osób o umiarkowanych dochodach). Wspomniane spory kończyły się zwykle wieloletnimi postępowaniami przed Komisją Europejską (KE), a następnie Trybunałem Sprawiedliwości Unii Europejskiej (TSUE). Stąd też trudno dziwić się temu, że na forum UE od lat toczy się ożywiona dyskusja na temat kierunków unijnej polityki w zakresie budownictwa społecznego ${ }^{14}$.

Biorąc pod uwagę powyższe, zasadne wydaje się dokonanie analizy prawnej, która pozwoli odpowiedzieć na pytanie, czy realizacja programu społecznego budownictwa czynszowego przez spółki komunalne, w tym towarzystwa budownictwa społecznego, może zostać uznana za przejaw usług świadczonych w ogólnym interesie gospodarczym (dalej także UOIG). W tym celu zostanie dokonana analiza dotychczasowego orzecznictwa TSUE oraz rozstrzygnięć wydanych przez Komisję Europejską. Ponadto przedmiotem badań będzie także decyzja Komisji nr 2012/21/UE z dnia 20 grudnia 2011 r. w sprawie stosowania art. 106 ust. 2 Traktatu o funkcjonowaniu Unii Europejskiej do pomocy państwa $\mathrm{w}$ formie rekompensaty $\mathrm{z}$ tytułu świadczenia usług publicznych, przyznawanej przedsiębiorstwom zobowiązanym do wykonywania usług świadczonych w ogólnym interesie gospodarczym ${ }^{15}$. Tak zakreślone pole badań wydaje się uzasadnione m.in. tym, że na gruncie decyzji 2012/21/UE występuje bliżej nieokreślone pojęcie „budownictwa socjalnego". Co istotne, nowy program budownictwa społecznego został skonstruowany - zgodnie z rekomendacją Urzędu Ochrony Konkurencji i Konsumentów ${ }^{16}$ - właśnie na podstawie warunków przewidzianych

${ }^{14}$ Parlament Europejski na podstawie rezolucji z dnia 11 VI 2013 r. w sprawie budownictwa socjalnego w Unii Europejskiej (2012/2293[INI]) zwrócił się do Komisji Europejskiej o objaśnienie definicji mieszkalnictwa socjalnego na podstawie wymiany najlepszych praktyk i doświadczeń między państwami członkowskimi. Zob. również stanowisko M. Calona, Housing Europe letter to Commissioner for Competition, Margrethe Vestager, z dnia 6 III 2016 r., http://www.housing-europe.eu/resource-657/better-eu-rules-for-better-services-of-general-interest-in-housing\#_ftn4 (dostęp: 14 V 2016).

${ }^{15}$ Dz.Urz. UE L 7 z 11 I 2012 r., s. 3, dalej „decyzja 2012/21/UE”.

${ }^{16}$ Pismo Prezesa Urzędu Ochrony Konkurencji i Konsumentów (UOKIK) z dnia 30 XII 2014 r. (znak DD0-0792-57(2)/14/AH, http://legislacja.rcl.gov.pl/ docs//2/265934/265942/265946/dokument144393.pdf (dostęp: 16 V 2016). 
w decyzji 2012/21/UE ${ }^{17}$. O ile przy tym nie budzi wątpliwości zastosowanie wyżej wymienionej decyzji w odniesieniu do budownictwa adresowanego do osób najuboższych, o tyle pewne wątpliwości mogą pojawić się w przypadku transferu tych środków na rzecz budowy lokali przeznaczonych dla osób o umiarkowanych dochodach.

Za koniecznością podjęcia przedmiotowych badań przemawia natomiast brak pogłębionych analiz w powyższym zakresie, a także występowanie licznych wątpliwości na gruncie reguł pomocy publicznej w związku ze stosowaniem podobnych programów społecznego budownictwa czynszowego w innych państwach członkowskich UE.

\section{Pomoc publiczna a usługi świadczone w ogólnym interesie gospodarczym}

\subsection{Pojęcie i istota pomocy publicznej}

Pomoc publiczna jest jednym z przejawów ingerencji w procesy gospodarcze przez szeroko rozumiane państwo. Wynika to z faktu, że przysporzenia dokonywane $\mathrm{w}$ ramach pomocy publicznej zmieniają pozycję konkurencyjną beneficjentów wobec innych przedsiębiorców ${ }^{18}$. Tym samym pomoc publiczna, nazywana również pomocą państwa, stwarza określone zagrożenia dla konkurencji i innych wartości gospodarki rynkowej. W celu minimalizowania tych zagrożeń konieczne stało się wykształcenie w porządku prawnym UE systemu kontroli i oddziaływania na publiczne środki wspierania gospodarki. Podstawę tej regulacji stanowi ogólny zakaz stosowania pomocy publicznej ${ }^{19}$. I tak, art. 107 ust. 1 TFUE $^{20}$ stanowi, że "z zastrzeżeniem innych postanowień przewidzianych w Traktatach, wszelka pomoc przyznawana przez Państwo

17 Zob. § 9 Rozporządzenia z dnia 20 X 2015 r. Rady Ministrów w sprawie warunków i trybu finansowania zwrotnego w ramach realizacji przez Bank Gospodarstwa Krajowego rządowego programu popierania budownictwa mieszkaniowego oraz minimalnych wymagań dotyczących lokali powstałych przy udziale tego finansowania (Dz.U. poz. 1720).

${ }^{18}$ B. Popowska, Rola państwa w obszarze pomocy publicznej, „Przegląd Ustawodawstwa Gospodarczego" 2002, nr 8, s. 2-3.

${ }^{19} \mathrm{~K}$. Horubski, Wspieranie gospodarki, w: Publiczne prawo gospodarcze, seria System Prawa Administracyjnego, pod red. R. Hausera, Z. Niewiadomskiego, A. Wróbla, t. 8A, Warszawa 2013, s. 760-761.

${ }^{20}$ Dawny art. 87 Traktatu ustanawiającego Wspólnotę Europejska, dalej „TWE”. 
Członkowskie lub przy użyciu zasobów państwowych w jakiejkolwiek formie, która zakłóca lub grozi zakłóceniem konkurencji poprzez sprzyjanie niektórym przedsiębiorstwom lub produkcji niektórych towarów, jest niezgodna $\mathrm{z}$ rynkiem wewnętrznym $\mathrm{w}$ zakresie, $\mathrm{w}$ jakim wpływa na wymianę handlową między Państwami Członkowskimi"21.

Pomoc publiczna jest zatem co do zasady zakazana, ponieważ narusza lub może grozić zakłóceniem konkurencji na rynku wewnętrznym $^{22}$. Prawodawca unijny postanowił jednak, że w określonych przypadkach pomoc państwa może być dopuszczona. Kategorie pomocy dozwolonej ex lege zostały wskazane w art. 107 ust. 2 TFUE, natomiast na podstawie art. 107 ust. 3 TFUE Komisja Europejska została wyposażona w swoistą władzę uznaniowa, która pozwala jej decydować o tym, jakie kategorie pomocy mogą zostać uznane za zgodne z rynkiem wewnętrznym ${ }^{23}$.

W literaturze przedmiotu przyjmuje się, że pomoc publiczną stanowi wszelka pomoc, która kumulatywnie spełnia następujące przesłanki:

1. jej beneficjentem jest przedsiębiorca $\mathrm{w}$ rozumieniu funkcjonalnym;

2. jest udzielona za pośrednictwem lub ze źródeł państwowych w jakiejkolwiek formie;

3. stanowi korzyść dla beneficjenta oraz jest selektywna;

4. grozi zakłóceniem konkurencji lub zakłóca ją przez sprzyjanie niektórym przedsiębiorcom, oraz

${ }^{21}$ Szerzej na temat pojęcia pomocy państwa zob. S. Dudzik, Pojęcie pomocy państwa oraz rola sądów krajowych w egzekwowaniu prawa pomocy państwa Unii Europejskiej - wprowadzenie i wyrok TS z 11.07.1996 r. w sprawie C-39/94 Syndicat français de l'Express international (SFEI) i inni przeciwko La Poste i inni, "Europejski Przegląd Sądowy” nr 1, 2016, s. 44 i n.

${ }^{22}$ B. Kurcz, Komentarz do art. 107 Traktatu o funkcjonowaniu Unii Europejskiej, w: Traktat o funkcjonowaniu Unii Europejskiej. Komentarz, pod red. A. Wróbla, t. 2: art. 90-222, Warszawa 2012, s. 448.

${ }^{23}$ Władza uznaniowa Komisji jest bardzo szeroka. Obejmuje ocenę natury gospodarczej i społecznej, która musi być dokonana w kontekście unijnym. Trybunał Sprawiedliwości UE, kontrolując legalność wykonywania tego uprawnienia, nie może zastąpić oceny Komisji własną oceną, ale może jedynie zbadać, czy ta ocena nie jest obarczona oczywistym błędem lub nie stanowi nadużycia władzy (zob. wyrok TSUE z dnia 12 XII 2002 r., sygn. C-456/00 Francja przeciwko Komisji, pkt 41). I. Postuła oraz A. Werner wskazują natomiast, że "można by odnieść wrażenie, że to nie Komisji, lecz Radzie przypada tutaj kluczowa rola decyzyjna, bo to Rada może uznać za zgodną ze wspólnym rynkiem pomoc nieodpowiadającą kryteriom wymienionym w art. 87 TWE". Ponadto autorzy ci podkreślają, że przy dominującej pozycji Komisji Europejskiej przyznanie pewnych uprawnień Radzie czy TSUE ma wpłynąć na uelastycznienie całego systemu i uczynienie go skuteczniejszym (I. Postuła, A. Werner, Prawo pomocy publicznej, Warszawa 2008, s. 110-111). 
5. wpływa na wymianę handlową pomiędzy państwami członkowskimi UE24.

Dopiero łączne spełnienie powyższych przesłanek spowoduje, że dane wsparcie będzie pomocą publiczną. Niespełnienie którejkolwiek z nich oznacza, że planowane wsparcie nie stanowi pomocy publicznej w rozumieniu art. 107 ust. 1 TFUE, a w konsekwencji do jego udzielenia nie będą miały zastosowania ograniczenia wynikające z przepisów o pomocy publicznej. Nie można przy tym pomijać faktu, że za adresatów pomocy publicznej mogą być uznani wyłącznie przedsiębiorcy ${ }^{25}$. Stąd też różne formy pomocy na rzecz konkretnych obywateli w celu ułatwiania nabycia mieszkań na własność (np. Mieszkanie dla młodych czy Rodzina na swoim), choć są potocznie nazywane "pomocą państwa”, to jednak nie należy ich utożsamiać z pomocą publiczna, o której mowa w art. 107 i 108 TFUE.

\subsection{Skutki uznania określonej działalności za usługę świadczoną w ogólnym interesie gospodarczym}

Ogólne zasady dotyczące pomocy publicznej przewidziane w art. 107 ust. 1 TFUE pozostają w ścisłej relacji z art. 106 ust. 2 TFUE. Przepis ten stanowi bowiem podstawę do wyłączenia określonego rodzaju działalności (tj. działalności w zakresie świadczenia usług w ogólnym interesie gospodarczym) spod europejskich reguł konkurencji, w tym spod ogólnych reguł dotyczących pomocy publicznej.

Zgodnie z utrwaloną linią orzeczniczą Trybunału Sprawiedliwości UE, która ukształtowała się na kanwie sprawy Altmark Trans i Regierungspräsidium Magdeburgé ${ }^{26}$, jeżeli państwo, przekazując określonemu przedsiębiorstwu wynagrodzenie w zamian za świadczenie przez nie powierzonych mu usług w ogólnym interesie gospodarczym, przestrzega warunków wskazanych m.in. w orzeczeniu Altmark, to działa tym

${ }^{24}$ K. Kwapisz-Krygel, Postępowanie w sprawach dotyczacych pomocy publicznej. Komentarz, Warszawa 2015, s. 12-13. Podobnie: I. Postuła, A. Werner, op. cit., s. 26-27; B. Kurcz, Komentarz do art. 107 Traktatu..., s. 431.

${ }^{25}$ Pomoc publiczna, w rozumieniu art. 107 TFUE, może być przyznawana jedynie podmiotom, które stanowią przedsiębiorstwa w rozumieniu prawa UE, w związku z czym wszelkiego rodzaju środki pomocowe oferowane prywatnym konsumentom znajdują się poza zakresem tego przepisu. Zob. Decyzję Komisji z dnia 26 IV 2006 r. w sprawie N 142/2005, Low Carbon Car Grant Programme (Dz.Urz. UE C 207 z 30 VIII 2006 r., s. 2).

${ }^{26}$ Wyrok TSUE w sprawie C-280/00, Altmark, dalej "Altmark”. 
samym jak normalny rynkowy (prywatny) inwestor i nie uprzywilejowuje danego przedsiębiorstwa względem jego konkurentów. W takim bowiem przypadku przedsiębiorstwo wykonujące zobowiązania służby publicznej nie otrzymuje żadnych rzeczywistych korzyści i nie dostaje niczego ponad to, co uzyskałoby na normalnych rynkowych warunkach. W rezultacie otrzymywane wówczas przez przedsiębiorstwo wynagrodzenie nie stanowi dla niego żadnego przywileju (nie stawia go w lepszej sytuacji konkurencyjnej) i nie powinno być tym samym uznawane za pomoc państwa w rozumieniu art. 107 ust. 1 TFUE ${ }^{27}$.

Zakwalifikowanie danego wsparcia jako rekompensaty z tytułu świadczenia usługi publicznej ma doniosłe skutki prawne, a mianowicie środki stanowiące tzw. rekompensatę z tytułu UOIG, czyli dopuszczalne $\mathrm{w}$ ramach wyłączenia zawartego $\mathrm{w}$ art. 106 ust. 2 TFUE, nie wymagaja notyfikacji, a ich kontrola ma charakter ex post. W konsekwencji uznanie, że dana działalność mieści się w ramach usług świadczonych w ogólnym interesie gospodarczym, daje państwu członkowskiemu pewien zakres swobody w zakresie stosowania działań pomocowych na rzecz przedsiębiorców, którym powierzono świadczenie tych usług ${ }^{28}$.

\section{Ocena charakteru pomocy udzielanej podmiotom realizującym zadania w zakresie społecznego budownictwa czynszowego}

\subsection{Spółdzielnie mieszkaniowe, TBS-y i spółki gminne jako przedsiębiorcy}

Rządowy program popierania budownictwa mieszkaniowego przewiduje przysporzenia w postaci preferencyjnych kredytów oraz zabezpieczeń wykupu emisji obligacji. Co istotne, przysporzenia te są udzielane jedynie na rzecz następujących podmiotów: spółdzielni mieszkaniowych, towarzystw budownictwa społecznego (TBS), a także spółek handlowych z udziałem gminy. Wskazane podmioty, ze względu na specjalny cel swojej działalności, co do zasady nie działają w celach zarobkowych. Często

${ }^{27}$ Ł. Grzejdziak, Regulacja finansowania ustug publicznych w Europie, Warszawa 2015, s. 356-360.

${ }^{28}$ J. Kociubiński, Stosowanie Pakietu Altmark (I i II) wobec pomocy udzielanej przedsiębiorstwom świadczacym usługi w ogólnym interesie gospodarczym, „Folia Iuridica Wratislaviensis" 2012, vol. 1, no. 1, s. 179 i n. 
natomiast jedynym udziałowcem spółek komunalnych oraz TBS-ów są gminy, przez co mamy do czynienia ze szczególnym rodzajem podmiotów, powołanych do wykonywania precyzyjnie określonych zadańn ${ }^{29}$.Zgodnie natomiast $\mathrm{z}$ art. 107 ust. 1 TFUE pomocą publiczną jest jedynie pomoc udzielana przedsiębiorcom. Wobec powyższego pojawia się pytanie o to, czy tego rodzaju podmioty można w ogóle uznać za przedsiębiorców $\mathrm{w}$ rozumieniu art. 107 ust. 1 TFUE, a tym samym czy w stosunku do nich znajdą zastosowanie ogólne przepisy o pomocy publicznej.

Podejmując próbę odpowiedzi na powyższe pytania, należy w pierwszej kolejności zaznaczyć, że pojęcie przedsiębiorcy jest w prawie wspólnotowym rozumiane niezwykle szeroko. Odnosi się ono bowiem do wszystkich podmiotów prowadzących działalność gospodarczą, bez względu na ich formę prawna, sposób finansowania, a także niezależnie od tego, czy przepisy krajowe przyznają danemu podmiotowi status przedsiębiorcy. W konsekwencji mogą to być zarówno podmioty nastawione na zysk, jak i działające na zasadzie non-profit ${ }^{30}$.

Podobnie status prawny spółdzielni mieszkaniowych, TBS-ów oraz spólek komunalnych ocenia prezes Urzędu Ochrony Konkurencji i Konsumentów. W piśmie z dnia 30 grudnia 2014 r. stwierdził on jednoznacznie, że wszystkie wyżej wymienione podmioty "są przedsiębiorcami funkcjonującymi na otwartym i konkurencyjnym rynku budowy, sprzedaży i wynajmu mieszkań" ${ }^{\prime \prime}$. Nie ma przy tym znaczenia fakt, iż jedynym lub dominującym udziałowcem tego rodzaju spółek są jednostki samorządu terytorialnego ${ }^{32}$.

W odniesieniu do analizowanej kwestii podobne stanowisko wielokrotnie zajmowała również Komisja Europejska. Jako przykład wskazać można m.in. decyzję z dnia 3 lipca 2001 r. (State aid N 209/2001 - Ireland $)^{33} \mathrm{w}$ sprawie dotyczącej wsparcia udzielanego $\mathrm{w}$ formie gwarancji państwowych dla budownictwa społecznego. Na kanwie tej decyzji Komisja Europejska jednoznacznie stwierdziła, że gminy, a także podmioty będące własnością jednostek samorządu terytorialnego, zaspokajając potrzeby lokalnych społeczności w zakresie budownictwa społecznego,

${ }^{29}$ Mowa tutaj, oczywiście, o zadaniach własnych gminy lub zadaniach TBS enumeratywnie wskazanych $\mathrm{w}$ art. 27 u.n.f.p.b.m.

${ }^{30}$ A. Samelak, Samorzadowy zakład budżetowy a pomoc publiczna, Legalis 2012.

${ }^{31}$ Pismo Prezesa UOKIK z dnia 30 XII 2014 r., znak DD0-0792-57(2)/14/AH.

${ }^{32}$ A. Samelak, op. cit.

${ }^{33}$ Decyzja Komisji Europejskiej z dnia 3 VII 2001 r., State aid N 209/2001 - Ireland, SG (2001) D/289528. 
prowadzą działalność gospodarczą i konkurują na rynku budowy tanich mieszkań z innymi przedsiębiorcami.

Wobec powyższego nie ulega wątpliwości, że podmioty wskazane $\mathrm{w}$ art. 15a ust. 2 stanowią co do zasady przedsiębiorców (przedsiębiorstwa), o których mowa w art. 107 TFUE. Oznacza to, iż kumulatywne spełnienie przesłanek przewidzianych w tym przepisie będzie skutkowało uznaniem danego wsparcia za przejaw pomocy publicznej.

\subsubsection{Przesłanka selektywnej korzyści}

W literaturze przedmiotu przyjmuje się, że samo pojęcie "korzyści” powinno być rozumiane jako pewnego rodzaju uprzywilejowanie o charakterze gospodarczym. Zdaniem M. Kuleszy chodzi tu o „każde - w sensie ekonomicznym - przysporzenie, o charakterze nieekwiwalentnym w procesie wymiany, mające charakter przywileju, niezależnie od formy prawnej, w której go udzielono" 34 . Z kolei S. Dudzik uznaje, że „definicja pomocy w rozumieniu art. $87 \mathrm{i}$ n. TWE [obecnie $107 \mathrm{i}$ n. TFUE - dop. J.B., M.M.] powinna wskazywać przede wszystkim na każde świadczenie na rzecz przedsiębiorstwa pochodzące od państwa lub ze źródeł państwowych (zwiększające przy tym wydatki lub zmniejszające przychody państwa), które przynosi temu przedsiębiorstwu korzyść, jakiej nie mogłoby uzyskać w ramach normalnej działalności gospodarczej"35. Z cytowanych wyżej definicji płynie jednoznaczny wniosek, że kwestią drugorzędną jest forma korzyści. Należy przy tym wyraźnie podkreślić, iż nie można stworzyć zamkniętego katalogu instrumentów stosowanych przy udzielaniu pomocy. Wobec powyższego korzyścią mogą być zarówno określone przysporzenia (np. dotacje pieniężne lub rzeczowe, preferencyjne kredyty, gwarancje i poręczenia kredytów, inwestycje kapitałowe ze środków publicznych - zakup akcji lub udziałów ze środków publicznych, czy też zamówienia państwowe, w których stosuje się uprzywilejowanie określonych podmiotów $\left.{ }^{36}\right)$, jak i zwolnienia bądź ulgi podatkowe ${ }^{37}$.

${ }^{34}$ M. Kulesza, Pomoc publiczna dla przedsiębiorstw w RP. Rola gmin - uwagi wstępne na tle postanowień Traktatu rzymskiego i Układu o Stowarzyszeniu, „Przegląd Prawa Europejskiego" 1996, nr 1, s. 37.

${ }^{35}$ S. Dudzik, Pomoc państwa dla przedsiębiorstw publicznych w prawie Wspólnoty Europejskiej - między neutralnością a zaangażowaniem, Kraków 2002, s. 68.

${ }^{36}$ I. Postuła, A. Werner, op. cit., s. 33-34.

${ }^{37}$ Ibidem, s. 34. 
Korzyść może być zakwalifikowana jako przejaw pomocy publicznej tylko w takim przypadku, gdy jest ona "selektywna". Odpowiada to treści art. 107 ust. 1 TFUE, który stanowi o „uprzywilejowaniu niektórych przedsiębiorstw lub gałęzi gospodarki" ${ }^{\prime 3}$. Przesłanka selektywnego zastosowania środka państwowego stanowi zatem jeden z elementów konstytutywnych pojęcia "pomoc publiczna”. Jak wskazuje Ł. Grzejdziak, „aby środek objęty był hipotezą normy zawartej w art. 107 ust. 1 TFUE, musi zakłócać równowagę między beneficjentem pomocy a jego konkurentami. Pojęcie «pomoc państwa» obejmuje więc jedynie sytuacje zawierające element nierówności lub dyskryminacji, powstały w wyniku udzielenia pomocy" ${ }^{\prime \prime}$.

Selektywny charakter odróżnia środki stanowiące pomoc państwa od ogólnych środków wsparcia, które znajdują zastosowanie względem wszystkich przedsiębiorstw, we wszystkich sektorach gospodarki państwa członkowskiego. Poza zakresem art. 107 ust. 1 TFUE znajdują się więc środki ogólnej polityki monetarnej i fiskalnej, takie jak zmiany stóp procentowych, wprowadzenie nowych zasad opodatkowania bardziej korzystnych dla wszystkich przedsiębiorstw, dewaluacja waluty itp. ${ }^{40}$ Niemniej jednak analiza orzecznictwa TSUE prowadzi do wniosku, że większość środków wsparcia finansowanych z zasobów państwa jest $\mathrm{w}$ jakimś aspekcie selektywna ${ }^{41}$.

Przeprowadzona analiza materiału normatywnego, orzecznictwa oraz dorobku doktryny nie pozostawia żadnych wątpliwości co do spełnienia przesłanki „selektywnej korzyści” przez wsparcie przewidziane $\mathrm{w}$ ramach programu budownictwa mieszkaniowego. $\mathrm{W}$ analizowanym przypadku swoistą korzyść stanowi różnica między kosztem uzyskania

${ }^{38}$ B. Kurcz, Komentarz do art. 107 Traktatu..., s. 437.

${ }^{39}$ Ł. Grzejdziak, op. cit., s. 57.

${ }^{40}$ Ibidem, s. 57-58.

${ }^{41}$ Przykładowo, w sprawie Hiszpania przeciwko Komisji TSUE dokonał oceny prawa hiszpańskiego, które przewidywało ulgę podatkową z tytułu działalności eksportowej w celu promocji handlu międzynarodowego przez wspieranie inwestycji zagranicznych. Było to odliczenie od podatku w wysokości $25 \%$ od inwestycji rzeczywiście poniesionej w zakładanie przedsiębiorstw za granica, zakup akcji w przedsiębiorstwach zagranicznych, wydatki na promocję i reklamę związane z działalnością zagraniczną itp. Trybunał, powołując się na wcześniejsze sprawy, w tym na sprawę Ecotrade (wyrok TSUE z 1 XII 1998 r. w sprawie Ecotrade, sygn. C-200/97), orzekł, że taki środek może przynosić korzyści tylko jednej kategorii przedsiębiorstw, a mianowicie przedsiębiorstwom, które prowadzą działalność eksportową i w tym celu poczyniły określone inwestycje. Według ETS stwierdzenie tego faktu jest wystarczające, aby wykazać, że dany środek jest selektywny (wyrok TSUE z 15 VII 2004 r. w sprawie Hiszpania przeciwko Komisji, sygn. C-501/00). 
kredytu (zabezpieczeń wykupu emisji obligacji) na rynku komercyjnym w stosunku do kosztów jego uzyskania na warunkach preferencyjnych przewidzianych w programie. Analizowana pomoc ma przy tym charakter selektywny. Wynika to z faktu, że przyznawana jest tylko określonemu rodzajowi podmiotów wybranych w szczególnym trybie.

\subsubsection{Ocena pozostałych przesłanek}

W świetle celu niniejszego opracowania zbędne wydaje się podejmowanie szczegółowej analizy poszczególnych przesłanek pomocy publicznej w stosunku do analizowanego systemu wsparcia. Niemniej jednak już pobieżna ocena głównych założeń rządowego programu budownictwa mieszkaniowego prowadzi do wniosku, że przewidziane w nim formy wsparcia spełniają pozostałe przesłanki pomocy publicznej, tj. (1) stanowią interwencję państwa przy użyciu zasobów państwowych; (2) mogą wpływać na handel między państwami członkowskim; (3) mogą zakłócić lub zagrozić zakłóceniem konkurencji. Nie ulega zatem wątpliwości, iż wsparcie wprowadzone nowelą u.n.f.p.b.m. co do zasady stanowi pomoc publiczną w rozumieniu przepisów unijnych.

Tymczasem finansowanie społecznego budownictwa czynszowego przez Bank Gospodarstwa Krajowego w formie preferencyjnych kredytów oraz gwarancji nabycia emisji obligacji zostało zakwalifikowane przez ustawodawcę jako „rekompensata za świadczenie usług w ogólnym interesie gospodarczym". Na tym tle powstaje zatem pytanie o dopuszczalność takiej kwalifikacji w świetle przepisów unijnych.

\section{Kwalifikacja społecznego budownictwa czynszowego jako UOIG}

\subsection{Pojęcie i istota UOIG w świetle art. 106 ust. 2 TFUE}

Ogólne reguły dotyczące konkurencji ulegają szczególnej modyfikacji w stosunku do przedsiębiorstw zobowiązanych do realizowania tzw. usług świadczonych w ogólnym interesie gospodarczym (services in general economic interest, Dienstleistungen von allgemeinem wirtschaftlichen Interesse). Zgodnie z art. 106 ust. 2 TFUE przedsiębiorstwa zobowiązane do zarządzania usługami świadczonymi w ogólnym interesie gospodarczym lub mające charakter monopolu skarbowego podlegają normom 
Traktatów, zwłaszcza regułom konkurencji, w granicach, w jakich ich stosowanie nie stanowi prawnej lub faktycznej przeszkody w wykonywaniu poszczególnych zadań im powierzonych.

Artykuł 106 ust. 2 TFUE pozwala zatem - na zasadzie wyjątku na pewne odstępstwa od ogólnych reguł konkurencji. Innymi słowy, przedsiębiorstwa zobowiązane do zarządzania usługami świadczonymi w ogólnym interesie gospodarczym przestrzegają reguł konkurencji, jeżeli ich stosowanie nie będzie stanowiło prawnej lub faktycznej przeszkody w wykonywaniu powierzonych tym przedsiębiorstwom zadań. Na mocy art. 106 ust. 2 dochodzi więc do swoistej zmiany wagi dwóch odrębnych wartości: reguł konkurencji i bliżej nieokreślonej wartości, jaka wiąże się z zaspokojeniem potrzeb społecznych realizowanych w związku z wykonywaniem $\mathrm{UOIG}^{42}$.

Pojęcie usług świadczonych w ogólnym interesie gospodarczym nie ma definicji legalnej. Jak wskazuje M. Szydło, „stanowią one w prawie wspólnotowym szczególną kategorię prawną, stanowiącą oryginalny wytwór tego prawa" ${ }^{43}$. Należy jednak zauważyć, że na poziomie soft law można znaleźć próby stworzenia uniwersalnej definicji UOIG. I tak, Komisja Europejska w komunikacie w sprawie usług użyteczności publicznej w Europie stwierdziła, iż za UOIG można uznać zarówno usługi rynkowe, jak i nierynkowe, które zostały sklasyfikowane przez państwa członkowskie jako wykonywane w interesie ogólnym ze względu na obowiązek świadczenia usług publicznych i mające charakter gospodarczy, nie zawsze ukierunkowane na osiągnięcie zysku ${ }^{44}$.

Próba wskazania zamkniętego katalogu potrzeb społecznych, które są zaspokajane w związku z wykonywaniem UOIG, jest w zasadzie niemożliwa. Niemniej jednak w doktrynie dokonuje się próby podziału usług w ogólnym interesie (niekoniecznie gospodarczym) na trzy zasadnicze kategorie. Wśród nich F. Grzegorczyk wymienia:

1. usługi w ogólnym interesie gospodarczym świadczone przez duże przedsiębiorstwa sieciowe (chodzi tutaj w szczególności o sektor

\footnotetext{
${ }^{42}$ Por. F. Grzegorczyk, Przedsiębiorstwo publiczne kontrolowane przez Państwo, Warszawa 2012, s. 114-115.

${ }^{43}$ M. Szydło, Pomoc państwa wspierająca świadczenie usług w ogólnym interesie gospodarczym w świetle najnowszego orzecznictwa wspólnotowego , Europejski Przegląd Sądowy” 2006, nr 2, s. 32.

${ }^{44}$ Zob. pkt 22 Komunikatu Komisji - Usługi użyteczności publicznej w Europie (Dz.Urz. WE C 17 z 19 I 2001 r.). Inne definicje pojęcia UOIG zob. w: A. Maziarz, Zasady ustalania rekompensaty z tytułu świadczenia usług w ogólnym interesie gospodarczym, „Przegląd Ustawodawstwa Gospodarczego" 2015, nr 8, s. 2-3.
} 
telekomunikacyjny, pocztowy, elektroenergetyczny, gazowy, transportowy $)^{45}$;

2. pozostałe usługi w ogólnym interesie gospodarczym (m.in. gospodarka odpadami, dostarczanie wody, nadawanie publicznych programów radiowych i telewizyjnych $)^{46}$;

3. usługi nieekonomiczne i niewpływające na handel (m.in. pobieranie i redystrybucja zasiłków natury fiskalnej, kontrola bezpieczeństwa nawigacji w przestrzeni powietrznej, a także prerogatywy państwa, takie jak wymiar sprawiedliwości czy bezpieczeństwo; należy jednak podkreślić, że ta kategoria dotyczy usług świadczonych w ogólnym interesie niegospodarczym, które nie są objęte art. 106 ust. 2 TFUE) ${ }^{47}$.

Niewątpliwie, cechą wspólną usług świadczonych w ogólnym interesie gospodarczym jest to, że mają one charakter rynkowy, tj. sa świadczone za opłatą. Charakter tych usług powoduje jednak, że nie zawsze podmioty działające na zasadach rynkowych (komercyjnych) sa zainteresowane świadczeniem tego rodzaju usług. Często okazuje się bowiem, że świadczenie określonego rodzaju usługi jest nierentowne, ale istotne z punktu widzenia ogólnego interesu gospodarczego ${ }^{48}$. W rezultacie państwo - w celu zapewnienia dostępu do określonego rodzaju usług - dopuszcza ograniczenie zasad konkurencji i powierza świadczenie UOIG określonemu przedsiębiorcy ${ }^{49}$. Jednocześnie powierzeniu wykonywania UOIG towarzyszy przyznanie pewnych przywilejów na rzecz przedsiębiorcy. Mogą one przybrać charakter praw wyłącznych (tj. przyznania de facto monopolu wykonywania określonej usługi) lub rekompensat ${ }^{50}$. Te drugie sprowadzają się do przyznania stosownego wynagrodzenia, które ma "kompensować" poniesione straty powstałe w związku z prowadzoną działalnością.

${ }^{45}$ Jak wskazuje F. Grzegorczyk (op. cit., s. 125), „ze względu na istniejącą bądź potencjalną transgraniczność wymienionych sektorów ich funkcjonowanie zostało w dużej mierze uregulowane prawem unijnym $[\ldots]^{\prime \prime}$.

${ }^{46}$ "W przypadku tych sektorów, Unia Europejska nie przyjęła co do zasady kompleksowych regulacji sektorowych, choć pewne aspekty ich funkcjonowania zostały niewątpliwie uregulowane" (ibidem).

${ }^{47}$ Ibidem, s. 125-127. Zob. również Opinię Komitetu Regionów w sprawie komunikatu Komisji do Parlamentu Europejskiego, Rady, Komitetu Ekonomiczno-Społecznego oraz Komitetu Regionów - Biała księga nt. usług użyteczności publicznej (2005/C 164/06).

${ }^{48}$ A. Maziarz, op. cit., s. 2-3.

${ }^{49}$ Ibidem.

${ }^{50} \mathrm{~J}$. Ząbkowicz, Finansowanie rynkowych usług użyteczności publicznej w UE. Pomoc publiczna versus zasady konkurencji, „Studia Ekonomiczne. Zeszyty Naukowe Uniwersytetu Ekonomicznego w Katowicach" 2015, nr 209, s. 241 i n. 
W doktrynie wskazuje się, że „celem art. 106 ust. 2 TFUE jest zagwarantowanie obywatelom Unii takich usług, które:

- po pierwsze, wprawdzie mogłyby być zapewnione przez mechanizm wolnorynkowy, jednakże których podaż wymaga bezpośredniej demokratycznej legitymacji i kontroli ze strony państwowych struktur, głównie w celu zagwarantowania wszystkim równego dostępu do tychże dóbr i usług;

- po drugie, których wolny rynek nie byłby w stanie wytworzyć w sposób na tyle pewny, niezawodny i na takim poziomie, jak tego wymaga dobro ogółu;

- po trzecie, których mechanizm wolnorynkowy nie byłby w stanie zapewnić (dostarczyć) tym obywatelom, którzy ich potrzebują, głównie ze względu na niską siłę nabywczą tych ostatnich osób"51.

Generalnie rozważania dotyczące usług świadczonych w ogólnym interesie gospodarczym prowadzą do pytania o to, czy do tego rodzaju usług mogą być zaliczane także usługi związane ze społecznym budownictwem czynszowym. Wydaje się jednak, że dokonanie tej analizy jest niemożliwe bez odniesienia do tzw. testu Altmark.

\subsection{UOIG w świetle testu Altmark}

Zgodnie z rozstrzygnięciem przyjętym przez Trybunał Sprawiedliwości UE w sprawie Altmark rekompensata przyznawana przedsiębiorstwom świadczącym UOIG nie stanowi zakazanej pomocy publicznej w rozumieniu art. 107 ust. TFUE, jeżeli kumulatywnie spełnione są cztery przesłanki.

Po pierwsze, przedsiębiorstwo będące beneficjentem wsparcia musi rzeczywiście być podmiotem obowiązków z tytułu świadczenia usług publicznych, a zobowiązania te muszą być jasno zdefiniowane. Przesłanka ta wymusza na państwach członkowskich obowiązek powierzania świadczeń UOIG poprzez odpowiedni akt władzy państwowej jeszcze przed rozpoczęciem ich świadczenia ${ }^{52}$. W praktyce najczęściej

${ }^{51}$ Traktat o funkcjonowaniu Unii Europejskiej. Komentarz, pod red. K. Kowalik-Bańczyk, M. Szwarc-Kuczer, A. Wróbla, t. 2, Warszawa 2012, s. 368 i n.

52 A. Maziarz, op. cit., s. 2-3; S. Dudzik, Rekompensaty z tytułu świadczenia usług w ogólnym interesie gospodarczym w prawie pomocy państwa Unii Europejskiej - wprowadzenie i wyrok TS z 24.07.2003 r. w sprawie C-280/00 Altmark Trans GmbH i inni przeciwko Nahverkehrsgesellschaft Altmark GmbH, „Europejski Przegląd Sądowy” 2016, nr 2, s. 47-48. 
są to akty kreacyjne danych przedsiębiorców, którzy wykonują tego rodzaju umowy (np. spółki komunalne), a także stosowne umowy wykonawcze (o powierzeniu UOIG).

Po drugie, parametry, na podstawie których wyliczana ma być rekompensata, muszą zostać ustalone uprzednio w sposób obiektywny i przejrzysty, tak aby uniknąć przyznania korzyści gospodarczej, która mogłaby uprzywilejować beneficjenta względem jego konkurentów ${ }^{53}$. M. Szydło podkreśla przy tym konieczność uprzedniego (ex ante) ustalenia parametrów wynagrodzenia. Jak wskazuje cytowany autor, gdy państwo "przekaże je [tj. usługi w ogólnym interesie gospodarczym dop. J.B., M.M.] danemu przedsiębiorstwu dopiero wtedy, gdy okaże się, że wykonywanie zobowiązań służby publicznej nie jest dla tego podmiotu opłacalne (tak aby dzięki wspomnianemu wynagrodzeniu przedsiębiorstwo mogło pokryć straty poniesione w związku z wykonywaniem służby publicznej), to takie wynagrodzenie stanowi pomoc państwa w rozumieniu art. 87 ust. 1 TWE"54.

W myśl trzeciej przesłanki testu Altmark wysokość rekompensaty nie może przekraczać kwoty niezbędnej do pokrycia całości lub części kosztów poniesionych w trakcie wywiązywania się ze zobowiązań z tytułu świadczenia usług publicznych, przy uwzględnieniu odpowiednich wpływów i rozsądnego zysku. Spełnienie tego warunku jest niezbędne dla zapewnienia, że beneficjent nie uzyskał żadnych korzyści, które zakłócają lub grożą zakłóceniem konkurencji przez wzmacnianie pozycji konkurencyjnej przedsiębiorstwa. Dopuszczalne jest natomiast uzyskanie przez przedsiębiorstwo, któremu powierzono wykonywanie UOIG, tzw. rozsądnego zysku ${ }^{55}$.

Czwarta - ostatnia przesłanka testu Altmark - stanowi, że w przypadku gdy wybór przedsiębiorstwa mającego wywiązywać się ze zobowiązań z tytułu świadczenia usług publicznych nie został dokonany zgodnie z procedurą przetargu publicznego, która pozwoliłaby na wybór oferenta świadczącego te usługi po kosztach najkorzystniejszych dla danej społeczności, poziom rekompensaty należy określić na podstawie analizy kosztów, jakie poniosłoby typowe, dobrze zarządzane przedsiębiorstwo dysponujące odpowiednimi środkami, biorąc pod uwagę odpowiednie wpływy i rozsądny zysk wynikający z wykonywania tych obowiązków. W literaturze przedmiotu wskazuje się, że celem wprowadzenia tej

\footnotetext{
${ }^{53}$ M. Szydło, op. cit., s. 38 .

${ }^{54}$ Ibidem.

${ }^{55}$ A. Maziarz, op. cit., s. 3.
} 
przesłanki było ograniczenie możliwości przyznawania przez władze publiczne określonym przedsiębiorstwom takich korzyści, które stawiałyby je w dużo korzystniejszej pozycji od ich bezpośrednich konkurentów ${ }^{56}$. Ponadto A. Maziarz podkreśla, że czwarta przesłanka wskazuje w pewnym sensie preferowany tryb wyboru przedsiębiorstwa, które ma realizować usługę w ogólnym interesie gospodarczym. W praktyce bowiem określenie rekompensaty dla przeciętnego, prawidłowo zarządzanego przedsiębiorstwa może napotkać wiele trudności.

Orzeczenie, które zapadło w sprawie Altmark, stanowi bez wątpienia swoisty kamień milowy orzecznictwa Trybunału Sprawiedliwości UE ${ }^{57}$. Należy jednak zauważyć, że późniejsze orzecznictwo TSUE oraz decyzje Komisji łagodziły kryteria przyjęte w wyroku w sprawie Altmark ${ }^{58}$. Przejawem tego jest pakiet aktów prawnych i dokumentów o charakterze soft law, który określa się mianem pakietu Almunii ${ }^{59}$. Fundamentalny element tego pakietu stanowi decyzja Komisji Europejskiej 2012/21/ UE z dnia 20 grudnia 2011 r. w sprawie stosowania art. 106 ust. 2 Traktatu o funkcjonowaniu Unii Europejskiej do pomocy państwa w formie rekompensaty z tytułu świadczenia usług publicznych, przyznawanej przedsiębiorstwom zobowiązanym do wykonywania usług świadczonych w ogólnym interesie gospodarczym, która ma zastosowanie m.in. do usług publicznych związanych z mieszkalnictwem socjalnym.

\subsection{Pojęcie mieszkalnictwa socjalnego występujące na gruncie decyzji 2012/21/UE}

Fundamentalne znaczenie dla wskazania ram prawnych dotowania mieszkalnictwa socjalnego ma decyzja 2012/21/UE. Określa ona warunki, na jakich pomoc państwa $w$ formie rekompensaty $z$ tytułu świadczenia usług publicznych, przyznana pewnym przedsiębiorstwom, którym powierzono wykonywanie usług świadczonych w ogólnym interesie gospodarczym, jest zgodna $\mathrm{z}$ rynkiem wewnętrznym i zwolniona z wymogu zgłoszenia określonego w art. 108 ust. 3 Traktatu ${ }^{60}$. Zgodnie

${ }^{56}$ Ibidem.

${ }^{57}$ S. Dudzik, Rekompensaty z tytułu świadczenia ustug..., s. 46 i n.

${ }^{58}$ Zob. np. wyrok Sądu UE (dawny Sąd Pierwszej Instancji) w sprawie T-137/10, Coordination bruxelloise d'institutions sociales et de santé(CBI) przeciwko Komisji, EU:T:2012:584.

${ }^{59}$ Ł. Grzejdziak, op. cit., s. 405-430.

${ }^{60}$ Decyzja 2012/21/UE stanowi element tzw. pakietu Almunii. Warto przy tym podkreślić, że decyzja nr 2012/21/UE zawiera katalog uproszczony w porównaniu do 
natomiast $z$ art. 2 decyzji 2012/21/UE znajduje ona zastosowanie m.in. w odniesieniu do rekompensaty za wykonywanie usług świadczonych w ogólnym interesie gospodarczym, „zaspokajających potrzeby społeczne w zakresie mieszkalnictwa socjalnego". Co istotne, Komisja Europejska w pkt 11 preambuły decyzji nr 2012/21/UE jednoznacznie wskazała, że „przedsiębiorstwa zajmujące się usługami socjalnymi, w tym zapewnianiem mieszkalnictwa socjalnego osobom w niekorzystnej sytuacji lub osobom w gorszym położeniu społecznym [podkreśl. J.B., M.M.], które nie posiadają wystarczających środków, aby pozyskać mieszkanie na zasadach rynkowych, powinny również korzystać z możliwości zwolnienia $\mathrm{z}$ wymogu zgłoszenia określonego w niniejszej decyzji, nawet jeśli kwota otrzymywanej przez nie rekompensaty przekracza określony w niniejszej decyzji ogólny próg dla rekompensaty".

Wobec powyższego nie ulega wątpliwości, że mieszkalnictwo socjalne stanowi przejaw usług świadczonych w ogólnym interesie gospodarczym. Należy jednak zauważyć, że pojęcie „mieszkalnictwo socjalne” nie zostało zdefiniowane w żadnym akcie prawnym, co jest przyczyną wielu sporów interpretacyjnych ${ }^{61}$. Ponadto wykładnię pojęcia "mieszkalnictwo socjalne" w pewien sposób komplikuje zestawienie treści preambuły z treścią normatywną decyzji. Zgodnie bowiem z pkt 11 preambuły decyzja ma zastosowanie do przedsiębiorstw zajmujących się usługami socjalnymi, w tym zapewnianiem mieszkalnictwa socjalnego osobom w niekorzystnej sytuacji lub osobom w gorszym położeniu społecznym, które nie posiadają wystarczających środków, aby pozyskać mieszkanie na zasadach rynkowych. Z kolei art. 2 ust. 1 pkt c) decyzji 2012/21/ UE - wskazujący zakres zastosowania decyzji 2012/21/UE - ogranicza się jedynie do zwrotu "mieszkalnictwo socjalne”, a tym samym jest pozbawiony dodatkowych zwrotów określających.

O skali sporu dotyczącego mieszkalnictwa socjalnego świadczy chociażby Rezolucja Parlamentu Europejskiego z dnia 11 czerwca 2013 r. w sprawie budownictwa socjalnego w Unii Europejskiej ${ }^{62}$. Aktem tym Parlament Europejski zwrócił się do Komisji o objaśnienie definicji mieszkalnictwa socjalnego na podstawie wymiany najlepszych praktyk i doświadczeń między państwami członkowskimi. Zaznaczył przy tym, że

szerszego katalogu warunków zgodności rekompensat z rynkiem wewnętrznym ustanowionych w zasadach ramowych UE (Ł. Grzejdziak, op. cit., s. 510-511).

${ }^{61}$ Zob. uwagi w przypisie 14.

${ }^{62}$ Rezolucja Parlamentu Europejskiego z dnia 11 VI 2013 r. w sprawie budownictwa socjalnego w Unii Europejskiej (2012/2293[INI]). 
mieszkalnictwo socjalne jest różnie pojmowane i zarządzane (często ze względu na elastyczność w ustalaniu priorytetów) w poszczególnych państwach członkowskich, regionach i przez społeczności lokalne ${ }^{63}$. Dotąd jednak nie została wprowadzona legalna definicja pojęcia "mieszkalnictwo socjalne". Tym samym ogromne trudności sprawia próba wskazania, jaki obszar społecznego budownictwa czynszowego mieści się w ramach tego pojęcia. Prowadzi to do istotnych problemów praktycznych, a także konfliktów pomiędzy deweloperami działającymi na rynku komercyjnym a przedsiębiorstwami, którym powierzono wykonywanie UOIG.

Wymiar sporu dotyczącego istoty pojęcia "mieszkalnictwo socjalne" obrazuje sprawa prowadzona przez Komisję Europejską w odniesieniu do organizacji budownictwa społecznego w Holandii. Co prawda, spór ten powstał jeszcze przed przyjęciem decyzji 2012/21/UE, jednak w świetle jej nieprecyzyjnych postanowień niewykluczone jest powstanie podobnych konfliktów w przyszłości. Wspomniany spór dotyczył programu społecznego budownictwa czynszowego przyjętego przez Holandię. Program ten został zakwestionowany 14 lipca 2005 r. przez KE. Jednym z zarzutów kierowanych wobec niego było to, że organizacje budownictwa społecznego udostępniają mieszkania na wynajem także zamożniejszej części społeczeństwa, a nie tylko grupom wrażliwym. W konsekwencji uznano, że organizacje te otrzymują pomoc państwa, a prywatni inwestorzy są takiej pomocy pozbawieni, przy czym obie grupy podmiotów zaczynają rywalizować w tym samym segmencie rynku.

Ostatecznie 15 grudnia 2009 r. Komisja Europejska podjęła decyzję dotyczącą mieszkalnictwa czynszowego w Holandii, w której uznała badany system za zgodny z zasadami unijnymi dotyczącymi pomocy państwa na podstawie art. 106 ust. 2 TFUE. Wydanie przedmiotowej decyzji, zatwierdzającej zgodność systemu z rynkiem wewnętrznym, zostało jednak uzależnione od złożenia przez Holandię określonych zobowiązań dotyczących dostosowania systemu do unijnych zasad w zakresie pomocy państwa. W szczególności wskazano, że fundusze państwowe nie mogą być wykorzystywane do finansowania działalności o charakterze handlowym, a mieszkania czynszowe powinny być przydzielane w sposób przejrzysty według obiektywnych kryteriów ${ }^{64}$.

${ }^{63}$ Zob. pkt 4 Rezolucji Parlamentu Europejskiego w rozdziale zatytułowanym „Dążenie do stworzenia europejskiej polityki mieszkalnictwa socjalnego".

${ }^{64}$ P. Lis, Selektywna społeczna polityka mieszkaniowa - wybór czy konieczność?, tekst dostępny w materiałach na posiedzenie Stałego Przedstawicielstwa Kongresu Budownictwa z dnia 31 V $2010 \mathrm{r}$. 
Holandia, kierując się wytycznymi Komisji Europejskiej, wyznaczyła następujące granice warunkujące dostępność obywateli do mieszkań socjalnych oferowanych $\mathrm{w}$ ramach $\mathrm{UOIG}^{65}$ :

1. za grupy wrażliwe uznano osoby, których dochód brutto nie przekracza 33 tys. euro rocznie, przy minimalnej płacy w Holandii na poziomie 17 tys. euro rocznie w 2010 r. (Eurostat 2010, EC 2010); szacuje się, że tak ustalony limit objął $43 \%$ populacji;

2. ustalono maksymalny czynsz w budownictwie czynszowym na poziomie 648 euro miesięcznie ${ }^{66}$.

$\mathrm{Na}$ tle powyższego sporu dotyczącego pojęcia "mieszkalnictwo socjalne" wykrystalizowało się jednak stanowisko, które można uznać za ugruntowane. Komisja Europejska, powołując się na art. 1 Protokołu nr 26 stanowiącego załącznik do TFUE, konsekwentnie przyjmuje, że państwom członkowskim przysługuje szeroki zakres uznania w kwestii decydowania o tym, co stanowi przejaw mieszkalnictwa socjalnego. Zdaniem Komisji Europejskiej powyższa ocena powinna być determinowana uwarunkowaniami lokalnymi zarówno ekonomicznymi, jak i historycznymi, społecznymi oraz kulturowymi ${ }^{67}$.

Powyższe rozstrzygnięcie jest niewątpliwie korzystne dla państw członkowskich, bowiem pozostawia im pewien zakres swobody w zakresie decydowania o tym, co może stanowić usługi świadczone w ogólnym interesie gospodarczym. W tym kontekście dochodzi do swoistego zderzenia dwóch systemów prawnych: unijnego oraz krajowego. Znając zatem ogólne wytyczne dotyczące tego, co należy rozumieć pod pojęciem mieszkalnictwa socjalnego występującym na

${ }^{65}$ Commission Decision C(2009) 9963 final of 15 XII 2009 concerning state aid E 2/2005 and N 642/2009 (NL).

${ }^{66} \mathrm{P}$. Lis, op. cit. Powyższe rozstrzygnięcie było de facto rezultatem kompromisu i wieloletniej debaty publicznej, jaka miała miejsce w Holandii.

${ }^{67}$ Komisja Europejska, Przewodnik dotyczacy stosowania przepisów prawa Unii Europejskiej z zakresu pomocy państwa, zamówień publicznych i rynku wewnętrznego do usług świadczonych w ogólnym interesie gospodarczym, w szczególności do usług socjalnych świadczonych w interesie ogólnym, Bruksela, 29 IV 2013 r., SWD(2013) 53 final/2, s. 26-27. Warto przy tym zauważyć, że Komitet Regionów UE stoi na jednoznacznym stanowisku, iż „określenie poszczególnych zadań przypisanych usługom publicznym o charakterze socjalnym, jak również charakteru i treści wynikających z nich obowiązków świadczenia usługi publicznej, należy do państw członkowskich i samorządów terytorialnych i w związku z tym Komisja nie ma uprawnień do interweniowania, gdy chodzi o warunki przyznawania usług socjalnych gospodarstwom-beneficjentom i identyfikację kategorii gospodarstw, których zasadnicze potrzeby socjalne nie są zaspokojone wskutek wyłącznego działania sił rynkowych". 
gruncie decyzji 2012/21/UE, możliwe jest dokonanie analizy, która pozwoli rozstrzygnąć to, czy znajdzie ona zastosowanie także w odniesieniu do społecznego budownictwa czynszowego realizowanego w Polsce.

\subsection{Mieszkalnictwo socjalne a społeczne budownictwo czynszowe - odniesienie decyzji 2012/21/UE do polskich uwarunkowań prawnych}

Punktem wyjścia do oceny tego, czy społeczne budownictwo czynszowe mieści się w ramach mieszkalnictwa socjalnego, jest konieczność konfrontacji dwóch autonomicznych pojęć. Mowa tutaj o pojęciu „usługi świadczone w ogólnym interesie gospodarczym", które występuje na gruncie prawa unijnego, oraz pojęciu "usługi użyteczności publicznej”. Trudność w porównaniu obu terminów wynika chociażby z faktu, iż pierwszy z nich - jak sygnalizowano wcześniej - nie ma definicji legalnej w prawie unijnym. Nie ulega przy tym wątpliwości, że pojęcia te nie są tożsame. W literaturze przedmiotu wskazuje się, że pojęcie usług świadczonych w ogólnym interesie gospodarczym zawiera się w pojęciu usług użyteczności publicznej, które obejmuje, oprócz usług rynkowych, także różnego rodzaju działalności nierynkowe zakwalifikowane w ten sposób przez państwo ${ }^{68}$. W konsekwencji można uznać, że zakres pojęcia „usługi użyteczności publicznej” jest szerszy od pojęcia „usługi świadczone w ogólnym interesie gospodarczym". W praktyce oznacza to, iż w przypadku braku szczegółowych reguł unijnych wyznaczających zakres określonych usług świadczonych w ogólnym interesie gospodarczym państwa członkowskie mają swobodę definiowania tego, co stanowi tego rodzaju usługi ${ }^{69}$. Można zatem przyjąć, że przykładem usług świadczonych w ogólnym interesie gospodarczym będą na gruncie polskiego systemu prawnego te usługi, które stanowią usługi użyteczności publicznej. Co jednak istotne, dotyczy to wyłącznie tych usług użyteczności publicznej, które mają charakter gospodarczy. Innymi słowy, nie będą kwalifikowane do katalogu usług w ogólnym interesie gospodarczym te usługi użyteczności publicznej, które mają charakter

${ }^{68}$ P. Lis, op. cit.

${ }^{69}$ Komunikat Komisji do Parlamentu Europejskiego, Rady, Komitetu Ekonomiczno-Społecznego oraz Komitetu Regionów. Biała Księga nt. usług użyteczności publicznej z dnia 12 V 2004 r. (COM[2004]374 final). 
nieekonomiczny (np. kontrola bezpieczeństwa nawigacji w przestrzeni powietrznej czy prerogatywy państwa).

W polskim systemie prawnym definicja usług użyteczności publicznej zawarta została w Ustawie z dnia 20 grudnia $1996 \mathrm{r}$. o gospodarce komunalnej ${ }^{70}$. Zgodnie $\mathrm{z}$ art. 1 tego aktu usługi użyteczności publicznej wpisują się w gospodarkę komunalną jednostek samorządu terytorialnego, a ich celem jest bieżące i nieprzerwane zaspokajanie zbiorowych potrzeb ludności w drodze świadczenia usług powszechnie dostępnych. W myśl art. 1 ust. 1 u.g.k. to właśnie do jednostek samorządu terytorialnego należy w Polsce obowiązek prowadzenia tego rodzaju działalności, która polega na wykonywaniu przez nie zadań własnych, mających na celu zaspokajanie zbiorowych potrzeb wspólnoty samorządowej. Katalog zadań własnych gminy został natomiast określony w Ustawie $z$ dnia 8 marca 1990 r. o samorządzie gminnym ${ }^{71}$. Zgodnie $\mathrm{z}$ art. 7 ust. 1 pkt 7 tego dokumentu zaspokajanie zbiorowych potrzeb wspólnoty należy do zadań własnych gminy i obejmuje m.in. gminne budownictwo mieszkaniowe, które może być prowadzone przez gminę w różnych formach prawnych, w tym także $\mathrm{w}$ formie spółek prawa handlowego (zob. art. 2 u.g.k. ${ }^{72}$ ).

Szczegółowe zasady prowadzenia gminnego budownictwa mieszkaniowego określa Ustawa z dnia 21 czerwca 2001 r. o ochronie praw lokatorów, mieszkaniowym zasobie gminy i o zmianie Kodeksu cywilnego $^{73}$. Akt ten nakłada na gminy obowiązek tworzenia warunków do zaspokajania potrzeb mieszkaniowych wspólnoty samorządowej. Gmina, na zasadach i w wypadkach przewidzianych w ustawie, ma zapewnić lokale socjalne i lokale zamienne, a także zaspokajać potrzeby mieszkaniowe gospodarstw domowych o niskich dochodach $^{74}$. Co istotne, gminne budownictwo mieszkaniowe powinno być skierowane także do osób, które z jednej strony mają zbyt wysokie dochody, aby ubiegać się o mieszkanie socjalne, a z drugiej zbyt niskie, żeby uzyskać kredyt hipoteczny lub wynająć mieszkanie na zasadach rynkowych.

70 Tekst jedn. Dz.U. 2016, poz. 573 ze zm., dalej „u.g.k.”.

${ }^{71}$ Tekst jedn. Dz.U. 2013, poz. 594 ze zm., dalej „u.s.g.”.

72 Zob. wyrok Wojewódzkiego Sądu Administracyjnego w Łodzi z 13 VI 2008 r., sygn. I SA/Łd 249/08.

${ }^{73}$ Tekst jedn. Dz.U. 2014, poz. 150 ze zm., dalej „u.o.l.”.

${ }^{74}$ Zob. Nowy program finansowania budownictwa czynszowego, Bank Gospodarstwa Krajowego, styczeń 2016. 
W celu realizacji tych zadań gmina może tworzyć i posiadać zasób mieszkaniowy ${ }^{75}$. Należy przy tym zauważyć, że w myśl art. 2 ust. 1 pkt 10 u.o.l. lokale stanowiące własność gminy albo gminnych osób prawnych lub spółek handlowych utworzonych z udziałem gminy, z wyjątkiem towarzystw budownictwa społecznego, a także lokale pozostające w posiadaniu samoistnym tych podmiotów należą do mieszkaniowego zasobu gminy ${ }^{76}$.

Konstatując powyższe rozważania, należy stwierdzić, że społeczne budownictwo społeczne (gminne budownictwo mieszkaniowe) stanowi usługę użyteczności publicznej. Co więcej, jest to niewątpliwie usługa o charakterze gospodarczym. Ze względu jednak na segment mieszkalnictwa, którego dotyczy, nie zawsze działalność tego typu będzie rentowna. Ogólny interes gospodarczy, a w szczególności fakt, że potrzeba mieszkaniowa jest podstawową potrzebą każdego człowieka, przemawia za tym, aby uznać ją za usługę świadczoną w ogólnym interesie gospodarczym.

Dokonana dotychczas analiza pozwala przejść do ostatniego etapu, a mianowicie do próby określenia, czy społeczne budownictwo czynszowe - realizowane m.in. na podstawie nowego programu budownictwa mieszkaniowego - mieści się w ramach mieszkalnictwa socjalnego, do którego znajdują zastosowanie łagodniejsze kryteria UOIG, a wynikające z decyzji 2012/21/UE. I tak, w pierwszej kolejności należy zauważyć, że przepisy unijne nie wyznaczają w sposób szczegółowy zakresu pojęcia "mieszkalnictwo socjalne”. W konsekwencji - jak wynika z utrwalonego stanowiska instytucji UE - zakres tego pojęcia wymaga doprecyzowania na gruncie przepisów krajowych. W polskim systemie prawnym interpretacja tego pojęcia jest nierozerwalnie związana $\mathrm{z}$ zadaniem gminy obejmującym gminne budownictwo mieszkaniowe. Jedną $z$ form realizacji tego zadania jest niewątpliwie społeczne budownictwo czynszowe. Stąd też należy przyjąć, że podejmowanie działalności w zakresie gminnego budownictwa mieszkaniowego (społecznego budownictwa czynszowego), którego szczegółowe zasady prowadzenia określa m.in. Ustawa z dnia 21 czerwca 2001 r. o ochronie praw lokatorów, mieszkaniowym zasobie gminy i o zmianie Kodeksu cywilnego, stanowi wyraz usług w ogólnym interesie gospodarczym.

${ }^{75}$ Ustawa o samorzadzie gminnym. Komentarz, pod red. P. Chmielnickiego, Warszawa 2013, nb. 17, s. 205. T. Moll wskazuje przy tym, że "gmina może (lecz nie musi) posiadać zasób mieszkaniowy" (T. Moll, Zakres działania i zadania gminy, w: Ustawa o samorzadzie gminnym. Komentarz, pod red. B. Dolnickiego, Warszawa 2016, s. 244-245).

${ }^{76}$ R. Dziczek, Ochrona praw lokatorów. Dodatki mieszkaniowe. Komentarz. Wzory pozwów, Warszawa 2015, s. 170, nb. 2 in fine. 
Jedynie na marginesie należy zaznaczyć, że program budownictwa mieszkaniowego przyjęty nowelą u.n.f.p.b.m. stanowi de facto uzupełnienie gminnych (lokalnych) instrumentów polityki mieszkaniowej ${ }^{77}$. Świadczy o tym m.in. treść art. 15a ust. 3 u.n.f.p.b.m., który uzależnia uzyskanie preferencyjnego finansowania od zawarcia stosownej umowy z gminą właściwą miejscowo dla planowanego przedsięwzięcia inwestycyjno-budowlanego. Co więcej, jednym z obligatoryjnych elementów wskazanej umowy jest określenie planowanej liczby lokali mieszkalnych utworzonych w wyniku realizacji przedsięwzięcia inwestycyjno-budowlanego, których najemcami będą osoby wskazane przez gminę, w tym osoby będące aktualnie najemcami lokali mieszkalnych wchodzących w skład mieszkaniowego zasobu gminy. Nie ulega zatem wątpliwości, że nowy program stanowi instrument do realizacji zadań własnych gminy związanych z budownictwem mieszkaniowym.

Relacje pomiędzy pojęciem "mieszkalnictwo socjalne”, o którym mowa w decyzji Komisji Europejskiej 2012/21/UE, a różnymi rodzajami działalności związanej z budownictwem mieszkaniowym przedstawia poniższy schemat.

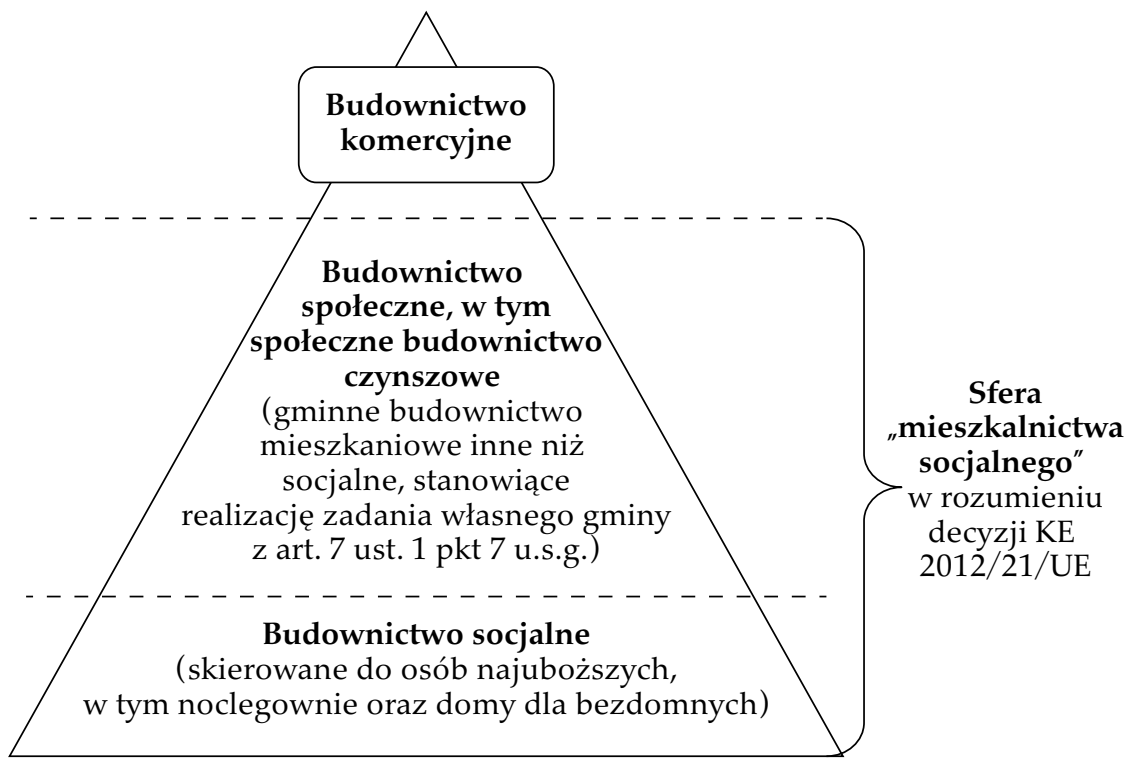

77 Uzasadnienie do rządowego projektu ustawy o zmianie ustawy o niektórych formach popierania budownictwa mieszkaniowego oraz niektórych innych ustaw, druk sejmowy nr 3586/VII kadencja z dnia 24 VI 2015 r., s. 2. 


\section{Podsumowanie}

Realizacja społecznego budownictwa czynszowego przez spółdzielnie mieszkaniowe, towarzystwa budownictwa społecznego oraz spółki komunalne $\mathrm{w}$ ramach nowego programu budownictwa mieszkaniowego może zostać uznana za przejaw usług świadczonych w ogólnym interesie gospodarczym. Przemawia za tym zarówno treść orzecznictwa ukształtowanego na gruncie art. 106 ust. 2 TFUE, z wyrokiem w sprawie Altmark na czele, jak i szczegółowe przepisy dotyczące wybranych rodzajów UOIG, które zostały określone w decyzji Komisji Europejskiej 2012/21/UE.

Wydaje się przy tym, że społeczne budownictwo czynszowe - przewidziane w nowym programie budownictwa mieszkaniowego - mieści się w ramach mieszkalnictwa socjalnego, do którego znajdują zastosowanie łagodniejsze kryteria UOIG, o których mowa w decyzji 2012/21/ UE. Przemawiają za tym następujące argumenty. Po pierwsze, przepisy unijne nie wyznaczają w sposób szczegółowy zakresu pojęcia "mieszkalnictwo socjalne". Tym samym nie powinno się go utożsamiać jedynie z budownictwem sensu stricto socjalnym, skierowanym wyłącznie do osób w niekorzystnej sytuacji lub w gorszym położeniu społecznym. Po drugie, brak szczegółowych przepisów unijnych wymaga doprecyzowania zakresu pojęcia "mieszkalnictwo socjalne" na gruncie przepisów krajowych. W konsekwencji zakres mieszkalnictwa socjalnego powinien być determinowany uwarunkowaniami lokalnymi zarówno ekonomicznymi, jak i historycznymi, społecznymi oraz kulturowymi. Stąd też może się on różnić w poszczególnych państwach członkowskich. Wreszcie po trzecie, w polskim systemie prawnym jednym z zadań gminy wskazanych w art. 7 ust. 1 u.s.g. jest gminne budownictwo mieszkaniowe, które obejmuje m.in. realizację zadań związanych ze społecznym budownictwem czynszowym, adresowanym do osób o umiarkowanych dochodach. Wobec powyższego należy przyjąć, że podejmowanie działalności w zakresie gminnego budownictwa mieszkaniowego (społecznego budownictwa czynszowego), którego szczegółowe zasady określa m.in. ustawa z dnia 21 czerwca 2001 r. o ochronie praw lokatorów, mieszkaniowym zasobie gminy i o zmianie Kodeksu cywilnego, stanowi wyraz usług w ogólnym interesie gospodarczym.

Należy jednak zauważyć, że poza zakresem niniejszych badań znalazła się analiza poszczególnych elementów rządowego programu budownictwa mieszkaniowego, w tym m.in. ocena sposobu, w jaki 
zostały określone warunki przyznawania rekompensaty, czy sama treść i forma prawna powierzania UOIG przedsiębiorcom. Zagadnienia te są z pewnością aktualne także w odniesieniu do inicjatyw podejmowanych przez niektóre gminy, które próbują obok rządowego programu budownictwa mieszkaniowego wdrażać także własne programy, realizowane przez ich spółki komunalne, a finansowane przy udziale środków z budżetu gminny. Biorąc pod uwagę trwającą na forum UE dyskusję na temat przyszłej polityki mieszkaniowej, a także zapowiedziane prace legislacyjne nad nowelizacją tzw. pakietu Almunii, który dotyczy UOIG, zasadne wydaje się dalsze monitorowanie zmian w tym obszarze. Nadto przemawia za tym zapowiadane przez rząd wdrożenie Narodowego Programu Budownictwa, którego jednym z filarów ma być budownictwo czynszowe. Niewątpliwie mechanizmy przygotowywane na potrzeby Narodowego Programu Budownictwa będą wymagały solidnej analizy prawnej w aspekcie ich zgodności z unijnymi regułami konkurencji.

\section{SOCIAL RENTAL HOUSING AS A SERVICE OF GENERAL ECONOMIC INTEREST}

\section{Su m mary}

Social rental housing is one of the possible instruments which are applied to ensure the satisfaction of housing needs. However, public funds which are transferred to entities that operate within this area should be usually classified as State aid. The analysis presented in this paper concerns the following question: is it possible to consider the operation of a social rental housing program as services of general economic interest. This question seems to be a topical issue because of a new legislative initiative aiming at establishing a governmental housing program that was implemented by the Act of 10 September 2015 which amended the Act on certain forms of supporting housing construction. The aforementioned program stipulates the legal frames for refundable and preferential financing that may be granted to specific entities in order to realise investments in social rental housing. The governmental housing program complements earlier local housing policies in force. What is significant is that the Polish legislator decided to qualify support granted as services of general economic interest, as referred to in Commission Decision 2012/21/UE of 20 December 2011 on the Application of Article 106(2) of the Treaty on the Functioning of the European Union to State aid in the form of public service compensation granted to certain undertakings entrusted with the operation of services of general economic interest. Applying Commission Decision 2012/21/UE to this situation raises some doubts as to the lack of clarity of a term "social housing". Due to a certain controversy over 
the abovementioned issue, the authors have attempted to examine whether the application of preferential provisions of Commission Decision 2012/21/UE to the social housing program is in accordance with the relevant provisions of EU competition rules.

Keywords: services of general economic interest - state aid - social rental housing - municipal housing 